\title{
Opismenjevanje otrok s slepoto
}

Aksinja Kermauner, Pedagoška fakulteta Univerze na Primorskem

\section{Bralno ovirani otroci}

$\mathrm{O}$ troci z ovirami branja ali bralno ovirani otroci (angl. print disabled children) oziroma otroci z zmanjšano bralno sposobnostjo so otroci, ki zaradi oviranosti ne morejo brati običajnih tiskanih publikacij. To so:

- otroci z govorno-jezikovnimi motnjami,

- otroci s primanjkljaji na posameznih področjih učenja,

- otroci z motnjami v duševnem razvoju (v nadaljevanju MDR),

- otroci s slepoto, slabovidnostjo in okvaro vidne funkcije,

- $\quad$ otroci z gluhoto, katerih prvi jezik je slovenski znakovni jezik (v nadaljevanju SZJ),

- oklevajoči bralci,

- otroci priseljencev (Haramija in Knapp, 2019).

Prilagoditve so za različne skupine specifične, npr. za otroke z gluhoto SZJ, za otroke z MDR lahko branje, v tem prispevku pa se bomo osredotočili na otroke $s$ slepoto, ki potrebujejo besedila v brajici (Braillovi pisavi).

\section{Bralna pismenost}

Pod pojmom pismenost razumemo funkcionalna in transferna znanja, veščine in strategije, ki jih osebe pridobijo v teku svojega življenja. Pismenost je $\mathrm{v}$ modernem, informacijsko naravnanem svetu prav gotovo ena najpomembnejših veščin. Predstavlja potencial, ki omogoča posamezniku 
socialno integracijo $\mathrm{v}$ družbo in mu zagotavlja osebni razvoj (Pečjak, 2004). Razvijanje osnovnih akademskih veščin (branja in pisanja) je zelo zapleten proces ter zahteva posebne kompetence vzgojitelja oz. učitelja, pazljivo pripravo in vzpodbudo (Jablan, 2016).

Bralna pismenost kot ena najpomembnejših kompetenc pogojuje razvoj večine preostalih zmožnosti, ki so cilj osnovnošolskega izobraževanja (Cankar, 2013), kasneje pa omogoča dejavno sodelovanje v sodobni družbi (Nolimal, 2013). Je vseživljenjski proces, razvijati pa se začne s poslušanjem preprostih literarnih besedil in opazovanjem ilustracij že v najzgodnejši otrokovi dobi (Batič in Haramija, 2013) kot zgodnja ali porajajoča se pismenost. Pojavlja se neodvisno od formalnega učenja, v okolju s tiskano in pisano besedo spontano ob običajnih dogodkih, ko otrok prepozna prve znane črke ob gledanju slikanic s starši in vzgojitelji, ob opazovanju reklam in oglasov na televiziji, ob likovnem branju pogostih napisov v okolici in podobno. Otrokom, ki zaradi različnih ovir nimajo možnosti za inkluzivno in enakopravno zagotavljanje priložnosti za učenje (Nolimal, 2013), je treba omogočiti prilagoditve gradiv za branje. Pravica vsakega otroka, tudi tistega, ki ima posebne potrebe, je biti opismenjen. Predvsem otroci s senzornimi ovirami imajo izjemno malo možnosti, da bi lahko uporabljali knjige in drugo pisno gradivo na nekonvencionalne načine, kot opisuje porajajočo se pismenost Clay (1966). Otroci s slepoto imajo že v izhodišču slabše možnosti, saj se na vsakem koraku ne srečujejo s pisavo, reklamami itn. kot njihovi videči sovrstniki, poleg tega pa imajo precej manj prilagojene literature (Hrastovšek, 20ı6).

Po avtorici Pečjak (2004) so za učinkovito branje in pisanje odgovorne sposobnosti vidnega in glasovnega zaznavanja. Bralna pismenost zahteva dobro razvite bralne in pisalne veščine, doseči jo je mogoče s prepoznavanjem in dekodiranjem različnih kodnih znakov. Če posameznik zaradi kakršnega koli vzroka teh sposobnosti ni zmožen razviti na visokem nivoju, potrebuje prilagoditve ali poseben tip gradiva, da bi lahko razumel njegovo vsebino (Haramija in Knapp, 2019). Osebe s težjimi okvarami vida zaradi zmanjšanega vidnega zaznavanja ne morejo brati grafične pisave oziroma pisave za videče (imenujemo jo tudi črni tisk), zato se opismenjujejo v brajici. Brez učenja in uporabe brajice ne moremo govoriti o celostni pismenosti oseb s slepoto (Murn, 2013). Opismenjevanje v brajici pa zahteva načrtno razvijanje specifičnih pristopov učenja in poznavanje posebnosti v razvoju otroka s slepoto.

\section{Posebnosti v razvoju otroka s slepoto}

Otrok s slepoto se razvija tako kot njegovi videči sovrstniki toliko časa, dokler njegov razvoj ni odvisen od vida (Koprivnikar, 2006). Ker ni 
vzpodbud iz okolja, se mehanizem vzburjenja vidnih centrov ne vzpostavi, to pa vpliva na vse vidike otrokovega razvoja. Otroci s težko okvaro vida večkrat kažejo določene razvojne težave, ki jih lahko opazimo pri njihovih vsakodnevnih aktivnostih ali igri: otrok manj raziskuje in se slabše uči $s$ posnemanjem. Dojenčki in malčki s slepoto se igrajo predvsem individualno in vzporedno. Brez spodbude odraslih pri igri ne vstopajo v socialne interakcije (Maljevac, 2019). Njihove senzomotorične izkušnje so zaradi omejenega vida siromašnejše, kar pogojuje tudi drugačno komunikacijo z okoljem in celoten razvoj komunikacijskih spretnosti (Eškirović, 2015). Nujno jim je zagotoviti najrazličnejše dražljaje, temelječe na preostalih čutih, saj to omogoča razvoj pojmov in predstav kot osnove $v$ procesu mišljenja govora in učenja (Čelešnik, 2009). V zgodnji mladosti je razvoj najintenzivnejši in vpliv okolja na otrokov razvoj najmočnejši (Žunič, 2019).

Za dejansko uresničevanje inkluzije v naši družbi se ne smemo več osredotočati na napake, ovire, motnje posameznega otroka s posebnimi potrebami. Torej ni pomembno, koliko in česa otrok ne zmore, temveč to, kako in v kakšnem obsegu mu pomagati, da bo čim več zmogel. Prepoznamo njegova močna področja in jih s prilagojenimi metodami razvijamo, podpiramo in izpostavljamo.

Že pri dojenčku s slepoto lahko razvijamo tipno in slušno zaznavo, ki ju bo kasneje še kako potreboval pri branju brajice in poslušanju literarnih del. Govor se pri otrocih s slepoto navadno razvija hitreje kot sposobnost gibanja, orientacije, zaznavanja okolice, ker pa imajo manj možnosti za spoznavanje predmetov in pojmov, se pogosto naslanjajo le na verbalni opis, brez konkretne izkušnje sveta, ki jih obdaja, predvsem predmetov, ki jih ni mogoče otipati, ker so preveliki, nevarni ipd. Otroci s slepoto zato dostikrat uporabljajo verbalizme, besede, ki jim ne poznajo pomena, le obliko; semantična vsebina dostikrat ne odgovarja realnemu izkustvu (Matok, 2007). Izguba vida prisili otroke s slepoto $v$ formiranje odnosov samo z govorom, zato jim je treba besede za predmete, ki tipu in sluhu niso dosegljivi (oblaki, perspektiva, senca itn.), razložiti na primeren način.

Razvita domišljija, bogat besedni zaklad, poznavanje pojmov, besednih zvez, razumevanje povedanega in sposobnost poslušanja odločilno vplivajo na uspešnost učenja branja in pisanja v šolski dobi. Veliko pozornosti moramo nameniti samemu opisovanju igrač, predmetov, pripovedovanju po spominu, obnavljanju zgodbic, pravljic, učenju pesmic na pamet, prepoznavanju posameznih glasov znotraj besed (Koprivnikar, b. d.). Poslušanje pravljic, pesmic, zgodb, različnih glasov in šumov pripomore $\mathrm{k}$ spodbujanju zavestnega slušnega zaznavanja in selekciji slušnih dražljajev (Brvar, 20I4). Otroku s slepoto omogočimo, da posluša zvoke, ki so prijetni in se z njimi igra. Različno zveneče igrače in predmeti z zvočnimi 
učinki bodo močno popestrili otrokovo igro, hkrati pa razvijali slušno zaznavo (Zidarič, 20I4).

Večina otrok s slepoto v intelektualnih sposobnostih ne zaostaja za svojimi videčimi vrstniki. $\mathrm{V}$ povprečju imajo relativno visoko stopnjo razvoja govora, bogat besedni zaklad in sposobnost logičnega mišljenja, marsikateri otrok s slepoto pa celo prekaša sovrstnike po izjemnih sposobnostih pomnjenja podatkov ali števil (Murn, 200I).

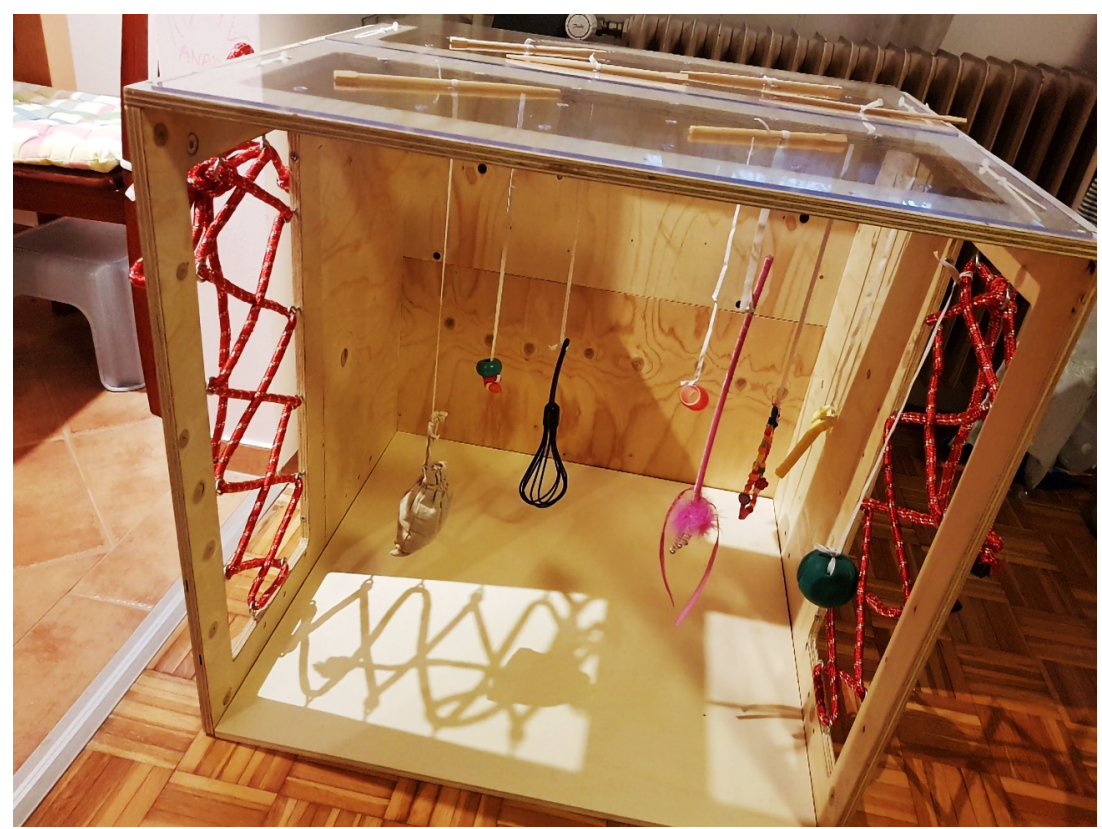

Slika I: Mali prostor, kiga je razvila studentka Tanja Horvat Baum (vir: Tanja Horvat Baum).

Ker otrok s slepoto ne more posnemati, je upočasnjen njegov motorični razvoj. Po Brambringu (2007) ima predšolski otrok s slepoto v primerjavi s svojimi polnočutnimi vrstniki precej slabše razvite ročne spretnosti, kar je lahko ovira za učenje brajice, kajti te spretnosti so osnova taktilno-kinestetičnih funkcij, ki omogočajo prepoznavanje brajevih simbolov. Izjemen stimulans za otroka je t. i. mali prostor (angl. little room), $\mathrm{ki}$ ga je razvila Lili Nielsen (Cervo, 20I8). Prostor opremimo s predmeti različnih tekstur in zvokov, otroku pa ponudimo tudi preprosto tipno knjigo z enakimi teksturami, kot so na panelih malega prostora (Kovačič, 2019) (Slika I). S tem razvijamo otrokove sposobnosti za dešifriranje tipnih dražljajev (Grbović, 20I7), hkrati pa razvijamo občutek za lastno telo in njegove dele, saj v tej starosti otroci še nimajo jasnih predstav o telesu, gibi rok 
in prstov, ki bodo kasneje sodelovali pri opismenjevanju, pa še niso dovolj razviti in diferencirani (Koprivnikar, b. d.).

\section{Brajica}

Braillova pisava ali po slovensko brajica je dobila ime po genialnem francoskem slepem študentu Louisu Brailleu. Rojen je bil kot videč otrok v vasici Coupvray blizu Pariza. Kot triletni fantič je po nesreči v očetovi sedlarski delavnici popolnoma oslepel (Birch, 1997). Kljub slepoti se je vključil v vaško šolo in pod zaščito vaškega župnika Palluya in mladega, neobremenjenega učitelja Béchereta naredil dva razreda osnovne šole. Pri desetih letih so ga sprejeli na Kraljevi zavod za slepe otroke v Parizu, ki je bil prva šola za slepe na svetu. V zavodu so imeli poleg rokodelskih in akademskih predmetov tudi branje, vendar po metodi, ki jo je zagovarjal ustanovitelj šole Valentin Haüy, in sicer knjige z velikimi izbočenimi črkami. Branje je bilo počasno in težko, zato ga učenci niso marali. Leta I82I je Kraljevi zavod obiskal Charles Barbier, ki je služil v Napoleonovi vojski. Svojo pisavo, ki jo je imenoval nočno pisanje, je razvil za tajno sporočanje zaupnih podatkov v bojnih jarkih ponoči brez pomoči svetlobe in zvoka. Sestavljena je bila iz I2 pik, postavljenih vertikalno v dveh stolpcih (Bračič, 2009). Braille je prevzel njegovo idejo, vendar jo je pri petnajstih letih izpopolnil. Namesto dvakrat po šest pik je zmanjšal znake le na dvakrat po tri, torej šest, kar je mogoče zaobjeti z blazinico kazalca. Pike $\mathrm{v}$ celici so razpostavljene navpično $\mathrm{v}$ dveh vertikalah. Različna kombinacija pik v polju, ki ga imenujemo brajeva celica, pomeni črko. $Z$ različnimi kombinacijami dobimo 64 znakov. Pisava, ki ni analogna pisavi za videče, je zamišljena izredno sistematično, zato se je je informativno mogoče relativno hitro naučiti (Gerbec, 1999). Ima le 25 črk, za označevanje velike začetnice oz. verzalk se uporablja poseben predznak, prav tako tudi za zapisovanje števk. Braillov sistem zajema sedem skupin znakov. Za druge pomene osnovni skupini dodajamo pike, jo spustimo za eno horizontalo niže ali ji dodamo predznak.

Velikost brajeve celice, višina in velikost pike se pri različnih znamkah brajevih tiskalnikov in brajevih strojev nekoliko razlikujejo, vendar so večinoma $\mathrm{v}$ okvirih velikosti blazinice kazalca. Navadno brajeva celica meri 7,5 $\mathrm{mm}$ x 4,5 mm, razmak med pikami je $1,5 \mathrm{~mm}$, premer pike je I,5 mm, razmak med dvema brajevima črkama pa od 2 do $3 \mathrm{~mm}$ (Gerbec, 1999). Knjige v brajici so zato precej obširne: ena stran črnega tiska (tisk, ki ga uporabljamo videči) sta dve strani in pol v brajici, zato se čedalje bolj uveljavlja branje s pomočjo brajeve vrstice, ki je dodatek k običajnemu računalniku in osebi s slepoto nadomešča zaslon. Postavljena je pred tipkovnico običajnega računalnika, na njej pa je vrsta majhnih lukenj, skozi 
katere se na površino $s$ pomočjo piezo-električnih modulov dvignejo in pogrezajo kroglice, različna kombinacija teh kroglic pa predstavlja določeno črko v brajici. Na brajevi vrstici oseba s slepoto lahko bere besedila, ki so linearna, recimo $\mathrm{v}$ formatu word, tipka pa na običajno tipkovnico z uporabo tipk namesto miške. Tako lahko oseba s slepoto dostopa do vseh elektronskih dokumentov, knjig na nosilcih, spletnih vsebin in socialnih omrežij, če le strani omogočajo tudi tekstovne alternative za vse netekstovne vsebine, npr. slike, zemljevide in druge grafične komponente. Vsa funkcionalnost interneta mora biti dostopna preko tipkovnice (Kermauner, 2018a).

Z brajico lahko zapišemo praktično vse: črke, števke, ločila, besedne poudarke, matematične izraze in fizikalne formule, kemijske enačbe, rimske števke, celo note. Zaradi potreb po novih znakih, razvijajočega se računalništva in prehoda na brajevo vrstico so osnovni brajevi celici dodali še sedmo in osmo piko. Iz tega sestava je mogoče kombinirati kar 252 brajevih znakov (Gerbec, 1999).

Brajica je mednarodna pisava, uporabljajo jo tako Arabci, Kitajci in Japonci. Preden pa je bila globalno sprejeta, je preteklo kar nekaj časa. Evropa jo je sprejela leta 1878, Amerika pa šele 1917 (Bavčar, 2009).

\section{Učenje brajice}

Brajica je za osebe s slepoto primarni izobraževalni medij (Jablan, 2016), čeprav naj bi poleg brajice poznale tudi črni tisk (slovenico oz. latinico), česar se naučijo z otipavanjem različnih oblik črk in z oblikovanjem le-teh v različnih materialih (glina, plastelin ...) ter s specialnimi pripomočki (pisanje na pozitivno folijo, tiflograf ...). Vsaka oseba s slepoto naj bi se namreč znala sama podpisati, saj se z lastnoročnim podpisom izkazuje istovetnost.

Osnovna razlika med črnim tiskom in brajico je v prevladujočem načinu percepcije: pri branju brajice je to tipno kinestetično prepoznavanje. Brajica ima za razliko od črnega tiska še tretjo dimenzijo - višino brajeve pike (Jablan, 2016).

Učenje brajice poteka po naslednjih stopnjah (Koprivnikar, b. d.):

I) predvaje za opismenjevanje v brajici;

2) učenje črk (prepoznavanje in pisanje);

3) učenje branja in pisanja.

Govorimo o primarnem opismenjevanju v brajici, to pomeni, da se otrok nauči brajice $\mathrm{v}$ zgodnjem otroštvu, kar je prav gotovo najučinkovitejše (Murn, 2013). 
Predvaje za opismenjevanje $\mathrm{v}$ brajici zajemajo orientacijo $\mathrm{v}$ mikro in makro prostoru. Otrok pokaže dele svojega telesa z obema rokama, jih poimenuje in poveže z njihovo funkcijo ter osvoji sredino telesa. Nato sledijo vaje za lateralizacijo, $s$ katerimi osvaja strani telesa, kar je osnova za orientacijo $\mathrm{v}$ prostoru, $\mathrm{v}$ brajevi celici, na brajevem stroju, kakor tudi orientacija na delovni površini, knjigi in listu. Delovna površina je prostor, ki ga otrok lahko zajame z rokami. Pogoj za uspešno orientacijo je obvladovanje pojmov, kot so miza, stol, prostor sedenja, gor/dol, levo/desno, spredaj/zadaj. Izhodiščna orientacijska točka se sedaj premakne na delovno površino in ne izhaja iz otroka, zato ga naučimo pravilnega raziskovanja delovne površine: najprej položi roke na sredino mize, $\mathrm{z}$ rokami previdno drsi proti zgornjemu robu mize, sledi razmik rok levo in desno in drsenje po zunanjem robu do spodnjega roba mize, nato pa razišče iz sredine diagonalno na levo in desno stran (Koprivnikar, b. d.).

Za branje in pisanje na brajev pisalni stroj je pomembna tudi moč prstov, zato $\mathrm{z}$ otrokom izvajamo vaje za razvoj motorike prstov, zapestja in rok, kot so na primer vožnja samokolnice, plazenje, potiskanje različnih predmetov, otroška joga, trganje papirja, stiskanje mokrih gob, ožemanje mokrih oblačil, škropljenje z brizgalko, vodno pištolico, injekcijo; manipuliranje s testom ali z glino; vlečenje vrvi, kegljanje, aktivnosti pri kuhanju ipd. (ibid).

\section{Fiziološka osnova}

V koži so za tip odgovorni tipni receptorji. Meissnerjeva telesca so bliže površini kože in jih je v blazinicah prstov približno Ioo na $\mathrm{m}^{2}$. Globje v podkožju so Vater-Pacinijeva telesca, ki reagirajo na pritisk. Za branje brajice so pomembni še kinestetični senzorni končiči, ki so v sklepih in vezivnih tkivih, in mišične ter tetivne čutnice, ki v mišičnih vlaknih zaznavajo raztezanje in krčenje pri gibanju mišic med branju (Gerbec, 1999). Raziskave so pokazale, da se z usmerjenimi vajami Meissnerjeva telesca, ki so zadolžena za tip, lahko razmnožijo do $50 \%$ (ibid.). Razvoj občutljivosti prstnih blazinic dosežemo z različnimi igrami, npr. s semensko škatlo: otrok s slepoto prebira različne večje ali manjše predmete ali plodove, hkrati pa ugotavlja njihove lastnosti (obliko, težo, teksturo, toploto), razvršča jih v predalčke, ki so v posebni škatli razporejeni kot osnovna brajeva celica (ibid.).

\section{Psihološka osnova}

Za tekoče branje brajice je treba združiti nevrofiziološko in psihološko komponento, to pa je odvisno od otrokove psihofizične zrelosti, razvitosti njegovega živčnega sistema in intelektualne razvitosti (Gerbec, 1999). 
Vidno-slušno-motorično triado zamenja tipno-slušno-motorična triada (Jablan, 2016). Pri prepoznavanju brajevega znaka se odvija proces analize in sinteze pik v brajevem znaku. Najprej bralec s slepoto razčleni pozicijo pik v skupini, nato pa jih zopet združi. Na začetku bo otrok s slepoto naredil veliko nepotrebnih gibov s kazalcema: ugotavlja razdaljo pike do pike, kroži po njem. Cilj je seveda simultano prepoznavanje znaka s hitrim drsenjem kazalcev čez brajeve črke. Dober bralec lahko glasno prebere tudi več kot 90 besed na minuto (Kermauner, 200I), kar je v povprečju za okoli $30 \%$ počasneje od branja videčih (Murn, 2013). Bralna hitrost pa se lahko zmanjša zaradi nelinearnih besedil (stolpci, preglednice itn.), saj je branje brajice linearno, torej črko za črko, vrstico za vrstico.

\section{Pedagoska osnova}

$\mathrm{V}$ procesu opismenjevanja v brajici so pri otroku s slepoto pomembna učna sredstva ter specialni pripomočki, učiteljeva usposobljenost in njegovo znanje, specialne metode in tiflopedagoški principi. Priporočene metode po avtorici Murn (2013) so:

- Individualni pristop: ker sistem usvajanja črk poteka po drugačnem zaporedju kot pri videčih, je smotrno, da je učenec pri začetnem opismenjevanju izločen iz razreda. Pripomočki za opismenjevanje so modeli brajeve celice, semenske škatlice, uvodni didaktični komplet za opismenjevanje in brajev stroj. Otrok s slepoto se ne uči črk po abecedi, ampak od lažjih brajevih znakov k bolj zahtevnim, strukturiranim. Ko je brajeva abeceda osvojena, se otrok s slepoto vključi v skupino polnočutnih vrstnikov, za enakovredno vključevanje v pouk pa potrebuje ustrezne pripomočke ter gradiva v brajici.

- Celostna metoda učenja jezika: po tej metodi učenci usvajajo cele besede s slikovnim materialom, zato otroku s slepoto omogočimo stik $s$ tipnim modelom, realnim predmetom, kasneje tudi tipno sliko.

- Lastna aktivnost: otroka s slepoto je treba ves čas spodbujati in ga motivirati. Procesi govorjenja, branja in pisanja se povezujejo v njegove lastne jezikovne vzorce in izkušnje. Učenec s slepoto naj sam napiše zgodbo in jo prebere. Več, kot bo bral, boljši bralec bo.

Otroka s slepoto opismenjuje tiflopedagog, kasneje pa lahko vadi in utrjuje brajico tudi z razrednim učiteljem (Hrastovšek, 20ı6) ali izvajalcem dodatne strokovne pomoči (specialnim in rehabilitacijskim učiteljem, inkluzivnim učiteljem). Jablan (2016) je po Chall povzela šest razvojnih faz, skozi katere gredo otroci s slepoto, preden se naučijo tekoče brati in pisati brajico. $\mathrm{V}$ prvi, ničelni fazi, se videči otroci srečujejo z grafičnimi simboli na vsakem koraku, medtem ko otroci s slepoto redko pridejo v stik 198 
z brajico (Jablan, 2016). V tem obdobju je treba poskrbeti za čim več stika z brajico (igre, igrače, igroknjige, zidna pravljica z brajevimi napisi, tipni slikopisi itn.). Druga faza je začetek formalnega učenja branja in pisanja, $v$ tretji se otrok s slepoto uči tekoče brati in avtomatizira dekodiranje simbolov, ki pa je počasnejše kot dekodiranje simbolov črnega tiska pri videčih otrocih. $V$ četrti in peti fazi otrok s slepoto razume pomen besedila na več nivojih in ga je zmožen analizirati.

Učenci se na začetku učijo predvsem pravilnega tipanja v vodoravni legi, vračanja $v$ novo vrsto in ugotavljajo posamezne skupine točk od celice do celice. Vrstni red pri obravnavi brajevih črk je drugačen kot pri obravnavi latiničnih črk. Otroci najprej spoznavajo črke, katerih postavitev točk je bolj enostavna (Golob, 1999).

V slovenskem prostoru za opismenjevanje otrok s slepoto v brajici uporabljamo Abecednik Cvetke Rožanec iz leta 1969, ni pa enotnega dokumenta $s$ cilji in programom dela za opismenjevanje otrok s slepoto (Hrastovšek, 2016).

\section{Pripomočki za predopismenjevanje otrok s slepoto}

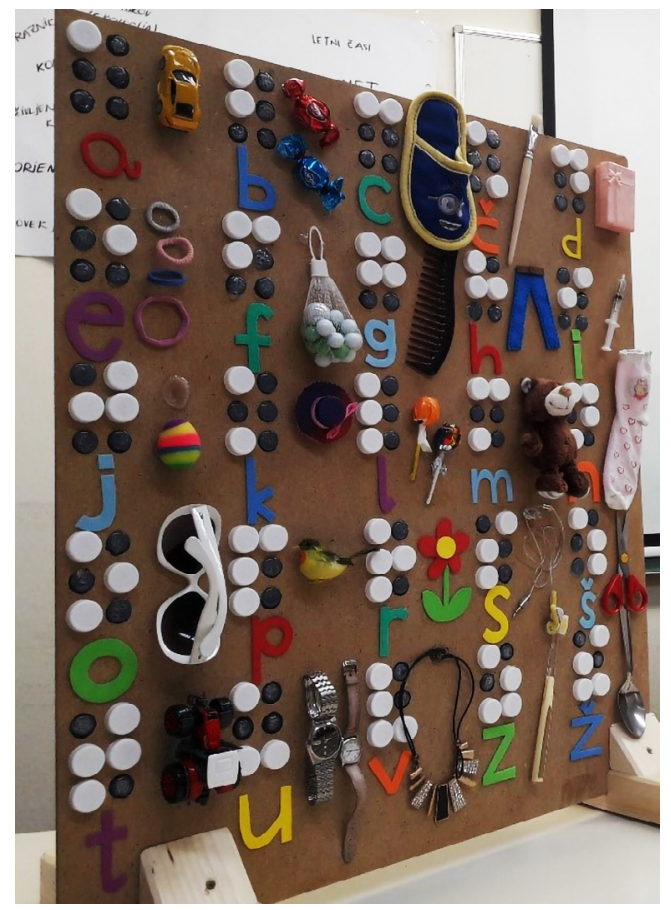

Slika 2: Brajeva tabla za pomočpri opismenjevanju (vir: Nives Jersin). 
Pomembno je, da ima otrok dobre predstave o predmetih in okolici (Murn, 2013), zato mu je treba omogočiti čim več izkustvenega učenja. Zavedati pa se moramo, da se informacije, ki jih dobimo s tipom, precej razlikujejo od informacij, ki pridejo v možgane z vidom (Claudet, 2009), zato se moramo pri prilagajanju vidnih podob v tipno obliko držati določenih pravil.

Vesna Murko (2015) je v magistrskem delu z naslovom Pike, ki se spreminjajo $\mathrm{v}$ črke razvila pripomočke za opismenjevanje na podlagi klasične brajeve semenske škatlice. Pripomočki poleg opismenjevanja postopoma, glede na otrokove spretnosti, razvijajo otrokovo orientacijo na površini, lahko pa se uporabljajo tudi za igro.

Uporabno tablo za opismenjevanje je naredila tudi študentka Inkluzivne pedagogike Nives Jeršin. Za brajeve pike je uporabila zamaške, ob vsaki črki pa obesila predmet, ki se začne na to črko (Slika 2).

\section{Tipni slikopisi}

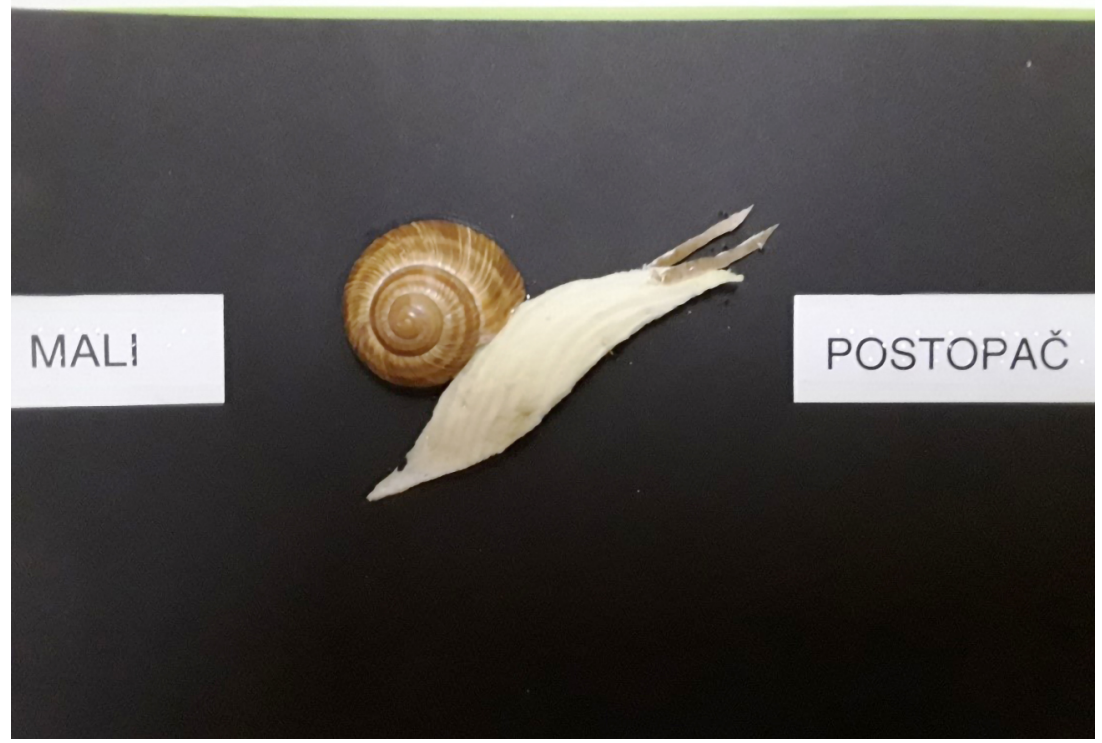

Slika 3: Slikopisi Anje Štefan, prilagojeni v tipno obliko (vir: Suzana Panić).

Definicije slikopisa so različne (Remškar, 2004; Sokolov, 2009; Štefan, 1995), vsekakor pa gre za preprosto besedilo, kjer so posamezne besede - praviloma so to samostalniki - nadomeščene s sličico. Slikopis lahko kot poseben tip slikanice uvrstimo med slikanico in ilustrirano knjigo, 
saj so sličice povezane v besedilo in oblikovane v zgodbo (Vavpot, 2018). Besedila je manj kot pri večini drugih vrst slikanice, zato je treba povzeti bistvo na zgoščen način (Panič, 2018). Slikopisi so dobro predbralno motivacijsko sredstvo, saj ilustracije v besedilu otroke spodbujajo, da vsebini sledijo skupaj s starši in da sodelujejo pri izgovorjavi besed (prav tam).

Veliko vidnih slikopisov se pojavlja v otroških revijah, avtorice pa so različne, najpogosteje jih sestavlja Anja Štefan. Tri njene slikopise je v tipno obliko prilagodila študentka Suzana Panić (2or8) (Slika 3).

Avtorice Kermauner, Lotrič in Skubic (Kermauner in Plazar, 2019) so ustvarile slikopise $\mathrm{z}$ naslovom Tipni slikopisi $\mathrm{I}$ in Tipni slikopisi 2. Besede so razporejene $\mathrm{v}$ zaporedju, ki je enako kot zaporedje učenja črk pri brajici: lažje črke (tiste z manj pikami) prej in težje kasneje. Uporabljen je spiralasto vezan album, $v$ katerem so na papirju živahnih barv ob brajici nalepljeni različni predmeti, ki jih mora otrok poiskati na sosednji strani (Slika 4).

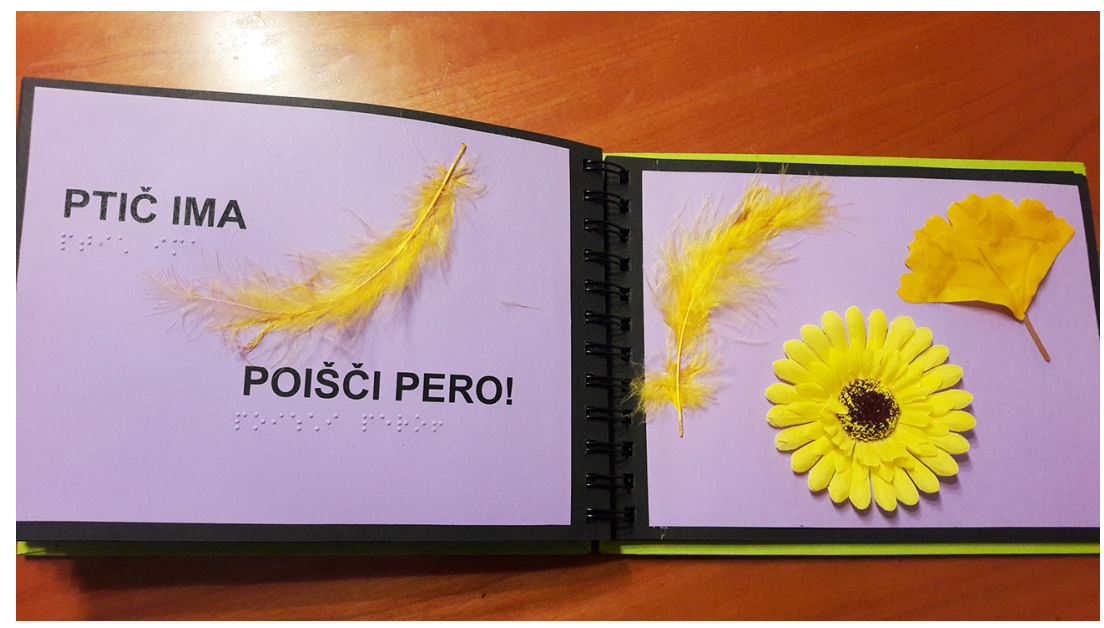

Slika 4: Tipnislikopisi 2 (vir: lastni arbiv avtorice).

Tipne slikanice

Tipne slike so poleg zvočnega opisa edini način, da prenesemo vidno podobo tako, da bo razumljiva tudi otroku s slepoto. $Z$ njimi se otroci učijo prepoznavanja in interpretiranja različnih oblik in tekstur, razvijajo precizno motoriko, selektivno tipno zaznavo ter razumevanje določenih oblik $\mathrm{v}$ procesu posploševanja oz. generalizacije, pridobivajo nove informacije, nove pojme za pojave ter utrjujejo izkušnje iz vsakdanjega življenja, pomagajo pa tudi razvijati jezik in besedišče. Tipne ilustracije pa tudi 
močno stimulirajo tip in tako mlajše otroke pripravljajo na branje brajice. Povečana občutljivost prstnih blazinic in z vsakodnevnimi dražljaji sproženo povečanje tipalnih telesc v koži sta eden od pogojev za kasnejše uspešno branje.

Tipne ilustracije naj prikazujejo manjše objekte, oblike, velikosti in površine, ki so otroku s slepoto domači in jih srečuje v vsakodnevnem življenju. Prav je, da pridejo otroci v stik tudi s takimi prikazi, ki jih lahko razberejo spontano in brez interpretacije odraslega (Kermauner, 2013).

Dobra tipna ilustracija je očiščena vseh nebistvenih informacij (posplošitev), količina informacij na njej je manjša, metodično in didaktično pa je prilagojena starosti slepega otroka (Brvar, 2000). Pomembna je tudi velikost prikaza - temeljno pravilo, ki izhaja iz prakse, je, naj se drži velikosti dveh razprtih dlani v širino ter v višino. Sama tipna informacija ne sme biti manjša od brajeve celice, kar pomeni, da mora biti med posameznimi znaki toliko prostora, da informacijo še lahko ločimo z blazinico prsta. Ker veliko otrok s slepoto še razloči močne barve, za tipne slike uporabimo močne, kontrastne barve. Skušamo se tudi držati naravnih sorazmerij (npr. mačka naj ne bo večja kot konj). Material naj spominja na stvarno podobo predmeta ali naj ga po posameznih lastnostih podpira (gladki materiali - hladne barve, hrapavi materiali - tople barve). Pomembna je tudi varnost - materiali in izdelava naj bodo varni (Kermauner, 2013).

Poznamo več tehnik izdelave tipnih prikazov:

- termo-vakuumska in mikrokapsulska ter termoformska tehnika, termopisalo,

- $\quad$ risanje na pozitivno folijo, s tiflografom ali z brajevim pisalnim strojem,

- sitotisk,

- slepi tisk,

- računalniška izdelava točkastih tipnih prikazov,

- samolepljive povoščene vrvice,

- kolaži iz najrazličnejših materialov,

- materiali za oblikovanje (glina, plastelin, fimo masa),

- lepilo, konturne in napihljive barve (Kermauner, 2004).

Tipne slikanice združujejo tipne slike z leposlovnim ali tudi stvarnim besedilom, ki je navadno v brajici in v povečanem črnem tisku za otroke s slabovidnostjo in njihove starše. Tipnih slikanic je malo, saj so navadno narejene le v nekaj izvodih, njihova izdelava pa je zamudna in draga.

Študentka Inkluzivne pedagogike Anica Toplak (2012) si je za glavni lik svoje tipne slikanice za pomoč pri opismenjevanju otrok s slepoto izbrala lik Kazalčka tipalčka, ki otroka vodi od števk I preko 2 do 9 in o, 
ki so s predznakom za števko v brajici enake črkam od a do j brez č (Slika 5). Sama je avtorica literarnega besedila Palček kazalček gre na potep, ki otroka usmerja $\mathrm{k}$ raziskovanju in ga motivira za osvajanje novih znanj. Povezavo med brajevimi črkami in številkami je prikazala v povsem inovativni luči in jo osmislila $\mathrm{z}$ domiselno izbranimi predmeti za posamezno črko. Za izdelovanje predmetov je uporabila različne naravne materiale ali pa material, ki najbolj spominja na realistično podobo predmeta, ki predstavlja črko.

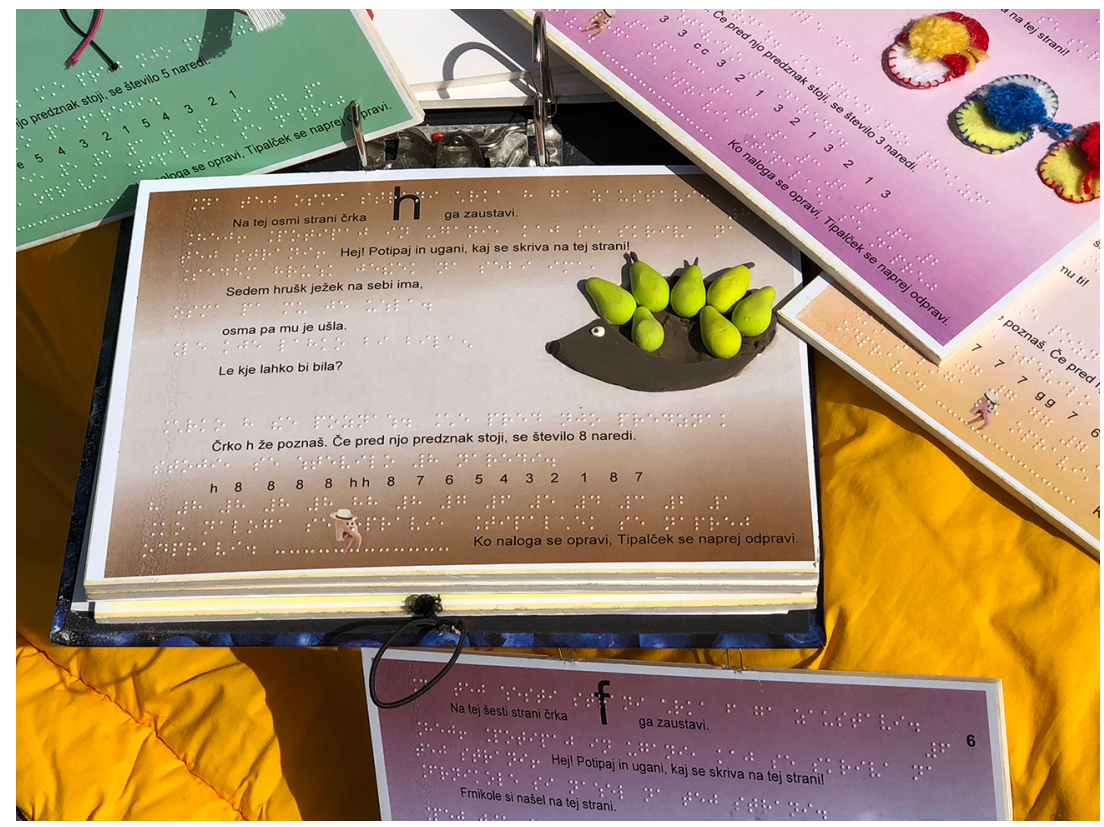

Slikas: Tipna slikanica Palcek kazalcek gre napotep (vir: Anica Toplak).

\section{Knjiga v škatli}

Ob tipnih slikopisih in tipankah lahko za predopismenjevanje za otroke $s$ slepoto uporabimo tudi knjigo $\mathrm{v}$ škatli, posebno zasnovano literarno delo, ki deluje večkanalno. Avtorica Vachulova (2009) je za zelo majhne otroke $s$ slepoto za ponazoritev pravljice Rdeča kapica dodala resnične predmete in izdelala knjigo $\mathrm{v}$ škatli s predmeti, prilepljenimi na posamezne strani. Nina Schmidt s Centra za izobraževanje, rehabilitacijo, inkluzijo in svetovanje za slepe in slabovidne, nekdanjega Zavoda za slepo in slabovidno mladino v Ljubljani (v nadaljevanju Center IRIS), je otrokom $s$ slepoto pripovedovala pravljico Bremenski godci, ob tem pa jim je za boljšo predstavo ponudila v otip razne plastične živali; pravljico Trije prašički 
je ponazorila z gradbenimi materiali (lego kocke, slama, lesene kocke) (Schmidt, 2013). Študentki Inkluzivne pedagogike na Pedagoški fakulteti Univerze na Primorskem Maja Zajec in Maja Mejač sta na ta način prilagodili pravljici Janko in Metka ter Zverjasec. Leta 2013 smo začeli razvijati nov projekt $\mathrm{z}$ naslovom Knjiga $\mathrm{v}$ škatli $=\mathrm{KnjiŠka}$ (angl. Book in the box $=$ BOOX), ki je vključeval naša teoretična spoznanja in praktične izkušnje pri delu z otroki s posebnimi potrebami (v nadaljevanju OPP).

KnjiŠka temelji na prilagoditvah in elementih, ki so izbrani glede na specifičnosti različnih OPP. Upoštevali smo odsotnost katerega izmed čutov, slabšo motiviranost, pomanjkanje razumevanja, motnjo pozornosti $s$ hiperaktivnostjo, slabo fokusiranost, slabo mobilnost in še druge omejitve v funkcioniranju.

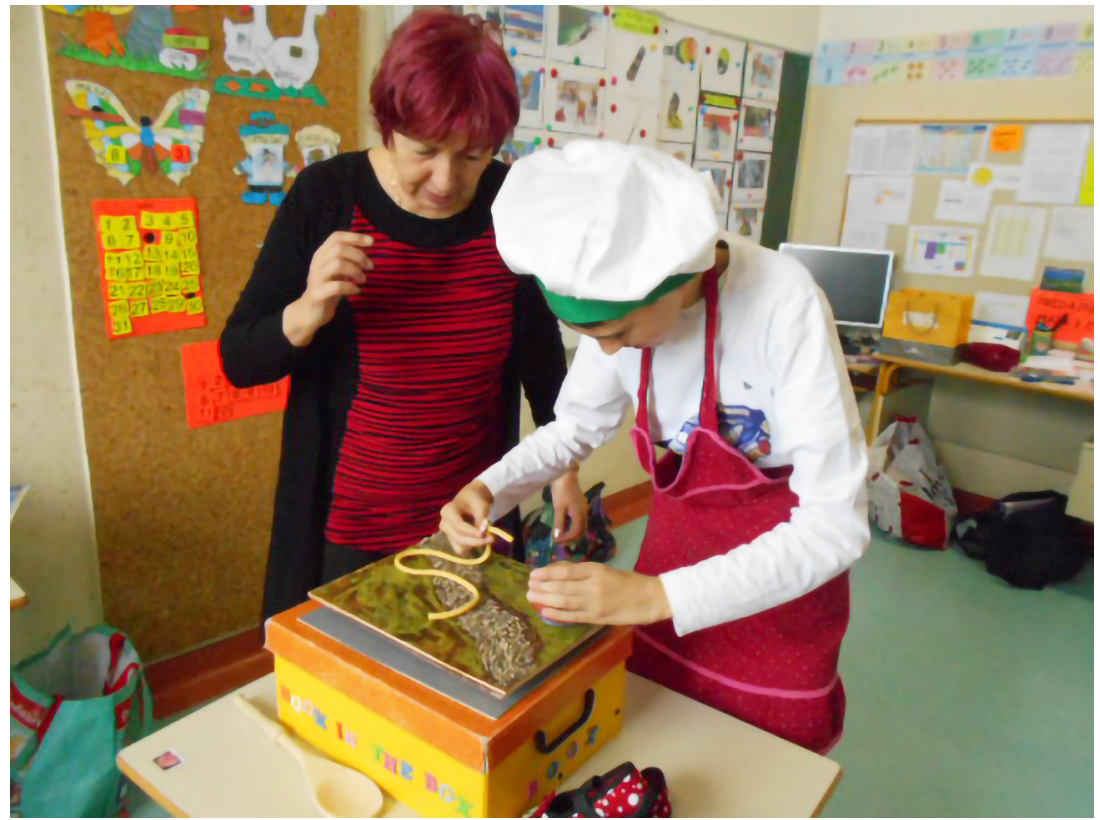

Slika 6: Knjiga v škatli Žiga špaget gre vsirni svet (vir: lastni arhiv avtorice).

Nastalo je nekaj zanimivih knjig v škatli: Žiga špaget gre v širni svet avtorice Kermauner je sestavljena iz slikanice, kjer sta avtorskemu besedilu ter nazornim vidnim in tipnim ilustracijam dodana še povečana pisava in brajica. Ilustracije so deloma opremljene z vonjem. Škatla vsebuje predmete, ki jih omenja zgodba (lonec, pokrovka, kuhalnica, špageti, kuharičino pokrivalo, čevlji ipd.), glavni osebi pa sta prikazani kot lutki oziroma igrači. Leseno škatlo $\mathrm{v}$ nekaj potezah spremenimo $\mathrm{v}$ igralno površino, ki se spreminja s prizori iz slikanice (štedilnik, stopnice, peščena 
pot, travnik, otroški peskovnik ...) (Kermauner, 20I4). Otrok s PP se s sestavinami Knjige v škatli lahko igra, medtem ko mu starejši prebirajo pravljico. $S$ predmeti dramatizira posamezen prizor, poustvari pravljico, si izmisli drugačen konec ... Tako s pomočjo igre dodatno motiviramo otroka, lažje se vživi v like, besedilo in ilustracije pa lahko sprejema s pomočjo različnih čutov (Slika 6).

Študentka PeF Univerze v Ljubljani Lucija Orehar je naredila prizorišča treh znanih slovenskih pravljic: Mojce Pokrajculje, Zvezdice Zaspanke ter Šivilje in škarjic. Študentka Inkluzivne pedagogike na PeF UP Maja Mejač se je lotila slikanice Bi se gnetli na tej metli Julie Donaldson, ki jo je prilagodila $\mathrm{v}$ lahko berljiv način in prepisala $\mathrm{v}$ brajico, škatla pa vsebuje lutke ter predmete iz zgodbe. Vez med tipno slikanico in knjigo v škatli je pravljica z lutkami študentke Inkluzivne pedagogike na PeF Univerze na Primorskem Ariele Abraham Čudna ovčka Beba in njeni običajni prijatelji, ki je prilagojena otrokom s slepoto in slabovidnostjo, gluhoto ter otrokom z motnjo $\mathrm{v}$ duševnem razvoju, otrokom z govorno-jezikovnimi motnjami in nadarjenim pa so namenjeni delovni listi z nalogami za utrjevanje (Kermauner, 20r8b).

Vse knjige $\mathrm{v}$ škatli izjemno razvijajo tip in so zato nadvse primerne tudi za opismenjevanje v brajici.

\section{Tipni kamišibaj}

Kamišibaj, japonsko papirnato gledališče, se je v zadnjem času zelo razširil v svetu, predvsem pa je popularen v Sloveniji. Kamišibaj je japonska tehnika pripovedovanja najrazličnejših zgodb ob slikah, ki jih vlečemo iz majhnega lesenega odra, imenovanega butaj. Pripovedovalec - kamišibajker - ob butaju, ki je navadno na mizi, sedi ali stoji (Sitar, 2018). Kamišibaj gledališče združuje pripovedovanje, torej slušne vtise, poleg tega pa še vizualne (menjavajoče se slike), zato pripoved in njeno sporočilo sprejmemo preko več zaznavnih kanalov (vizualni, slušni in kinestetični) (Škof, 2017). Za slepe je treba slike za butaj prilagoditi v tipni način. Študentka Silvija Belšak Viher je prilagodila slikanico E. Baguley Mali Pip in mavrica želja (Slika 7). Slike za butaj so narejene v tehniki kolaža, tako da jih je mogoče otipati.

Študentka Mihaela Škof je napisala avtorsko slikanico Ovčka Beti išče sestrico. Poleg tipnih slik za butaj je naredila še tipno slikanico, saj je ugotovila, da se vez med kamišibajkerjem in poslušalci (kyokan) prekine, medtem ko slepi otipavajo sliko (Slika 8). Zato jim je ponudila tipno slikanico hkrati s prikazom slike v butaju. 


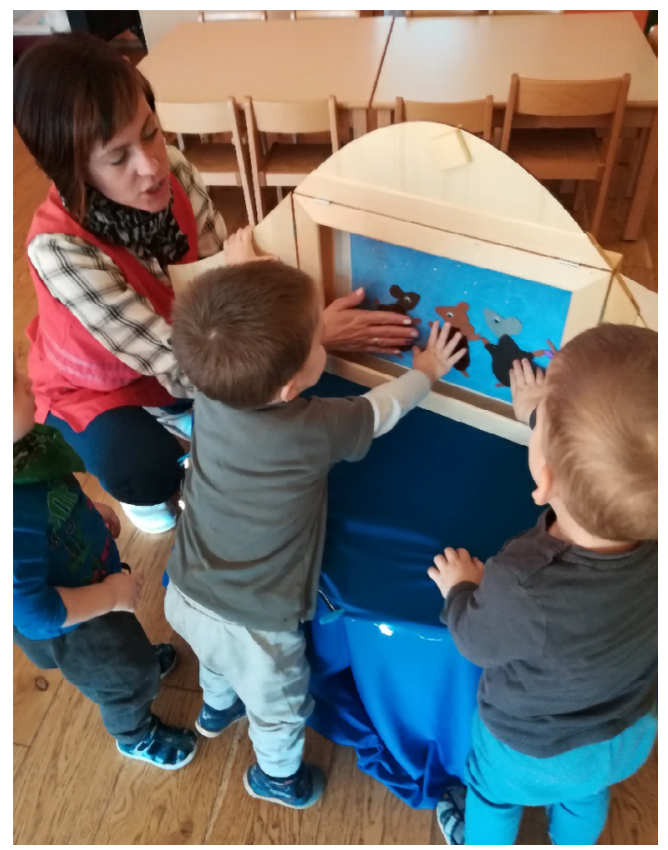

Slika 7: Mali Pip in mavrica želja (vir: Silvija Belsak Viher).

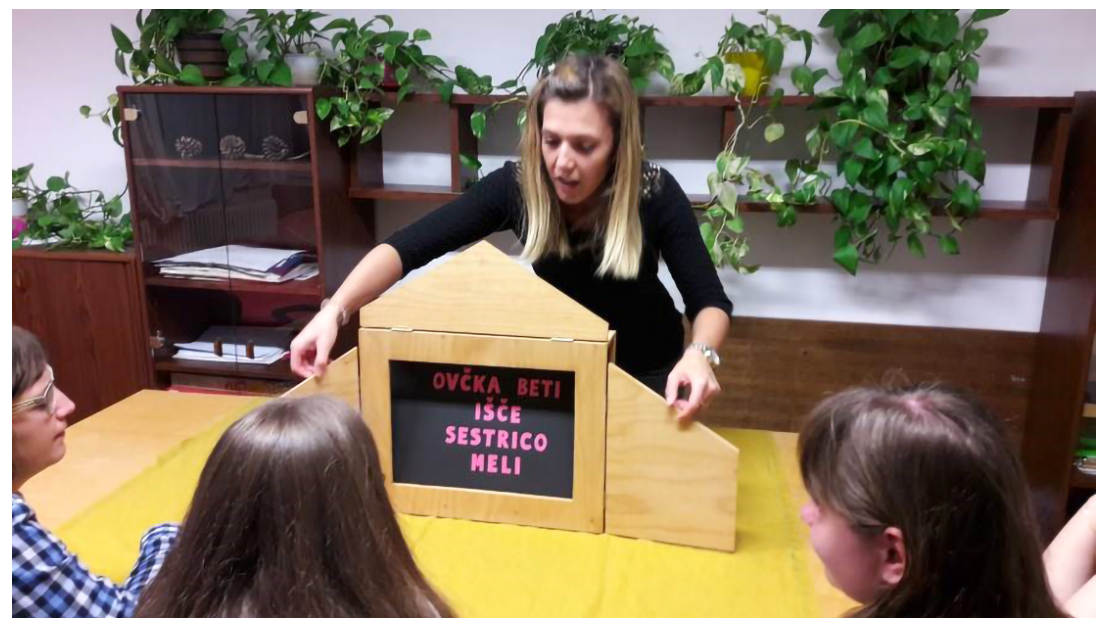

Slika 8: Ovčka Beti išče sestrico (vir: Mihaela Škof). 


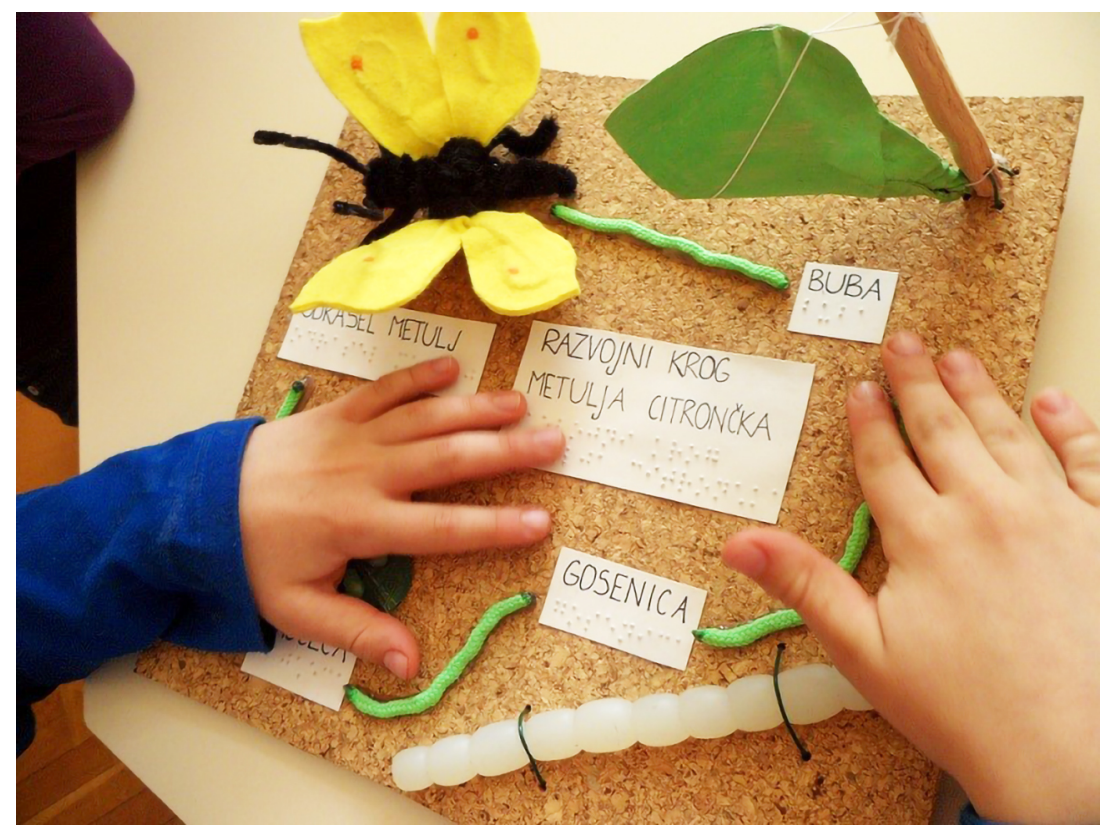

Slika 9: Razvojnikrog metulja.

Katja Draškovič in Ksenja Žmauc sta naredili tipno priredbo svoje zgodbe Metuljček plavček za tipni kamišibaj (Slika 9). Osebe s slepoto so ob pomoči didaktične igre, zgodbe in tipnega kamišibaja spoznavale proces pretvorbe gosenice v metulja (razvojni krog metulja).

\section{Zidna pravljica}

Stenska tipanka z naslovom Čudežno potovanje deklice Ade in kužka Benija je nastala na pustem stopnišču Centra IRIS. Njen prvotni namen je bil približati svet črk otrokom s slepoto, ki v svoji okolici ne najdejo veliko vzpodbud za branje. Med nastajanjem pa se je razvila v napeto potovanje deklice Ade in psička Benija, ki se odvija kar po stopnišču Centra. Zgodba o potovanju deklice Ade in njenega psička, ki gresta po zaklad, je opremljena $z$ glasbo in tipnimi vzpodbudami, unikatna stenska tipanka pa otrokom s slepoto in slabovidnostjo svet predstavi na multimodalen način, s pomočjo tekstur, zvoka in vidnih vtisov (Slika Io). Postopoma poimenuje osebe, živali in predmete od A do $\check{Z}$ ter ob konkretnih predmetih prikaže vse črke brajeve in vidne abecede. Otroci lahko spoznajo tipne lastnosti živali, ki nastopajo v pravljici (veverica, jež, sova, kača, rajska ptica ...), in jih tudi slišijo. Ob ogledu lahko zapojejo pesmico, ki jih spremlja vse 


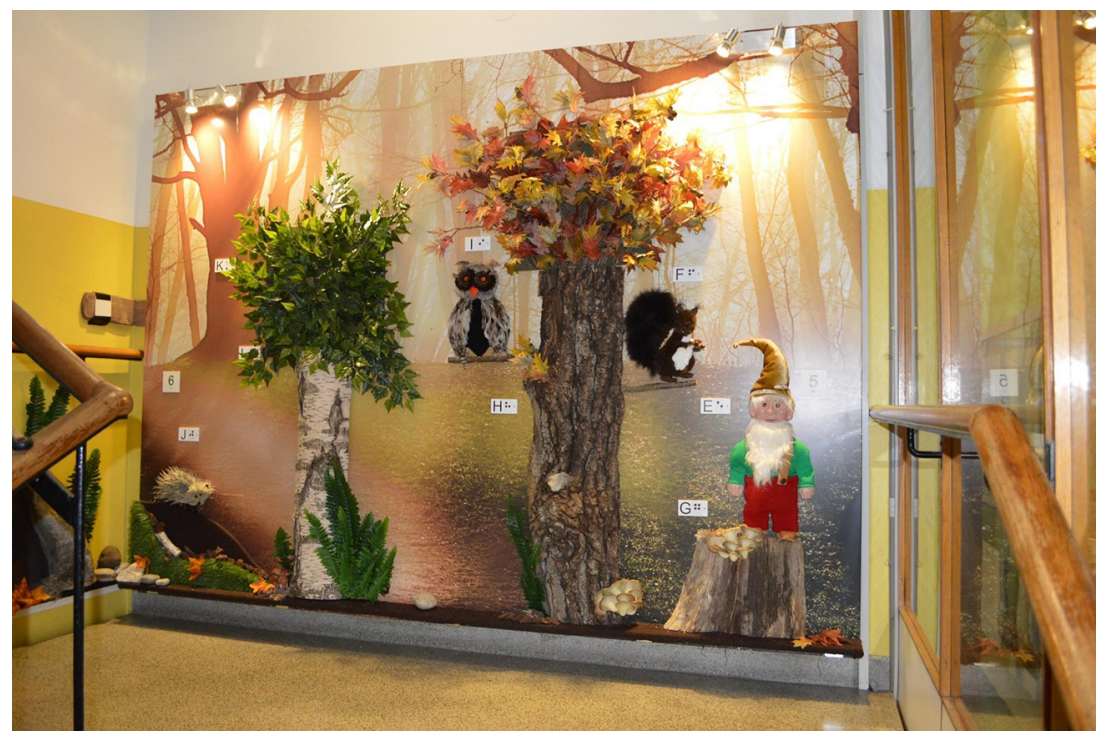

Slika Io: Zidna pravlica, slika Začarani gozd (vir: lastni arhiv avtorice).

do konca zgodbe in je napisana prav $\mathrm{v}$ ta namen. V potek zgodbe so vključene tudi tipne igre (sestavljanke).

Namen stenske tipanke je:

- S pomočjo igre omogočiti pridobivanje znanja, razvoj spretnosti in prepoznavanje okoliškega sveta, spoznavanje lastnosti oseb, živali in predmetov.

- Vaje čutil: prepoznavanje zvokov, treniranje eholokacije, razvijanje senzibilnosti prstov, precizne motorike, izpopolnitev tipne zaznave - pri otrocih s slabovidnostjo in s slepoto z ostankom vida tudi urjenje vida.

- Spoznavanje novega literarnega dela.

- Trening vsakodnevnih opravil: zapenjanje gumbov, zavezovanje pentelj, vezalk, zapenjanje zadrge, uporaba krtače za česanje itd.

- Razvijanje moralnih vrednot: zaklad niso materialne stvari, pač pa pristno prijateljstvo.

- Učenje nove pesmi, igranje na instrumente.

- Predopismenjevanje, opismenjevanje: spoznavanje posameznih črk in števk v brajici za otroke s slepoto.

- Sprostitev in zabava (različne sestavljanke).

Stenska tipanka združuje znanja s področja tiflopedagogike, grafične in tekstilne tehnologije, oblikovanja, glasbe in pripovedništva ter 208 
likovne upodobitve. Ob vsem tem pa je zelo pomembno to, da je otrok ob tipanki aktivno udeležen. Poleg vsega naštetega je namenjena vsem otrokom, mladostnikom in odraslim kot primer dobre prakse na področju otrok s posebnimi potrebami. Stensko tipanko je dve leti izdelovalo okoli Is strokovnjakov z različnih fakultet in je prvi tak projekt $\mathrm{v}$ Sloveniji in sosednjih državah. Praksa kaže, da je izjemno zanimiva za otroke s slepoto, ki vsak dan hodijo po stopnišču $\mathrm{v}$ svoje razrede in se je ne naveličajo. Ravno tako pa si jo ogleda veliko polnočutnih otrok, mladostnikov in odraslih, saj je njen sekundarni namen, da je multimodalno učenje za polnočutne otroke, didaktični pripomoček za študente, odrasle, strokovnjake in pedagoge, spodbuja senzibilizacijo polnočutnih otrok: zavedanje, da so med nami različni otroci (Urbas et al., 2017).

\section{Zaključek}

Čeprav je danes na trgu veliko avdio pomagal za osebe s slepoto in je veliko podatkov mogoče pridobiti po slušni poti, je opismenjenost v brajici neodtujljiva pravica otrok s slepoto. Bodisi da otrok začne tekoče brati brajico bodisi da uporablja brajevo vrstico za vsakodnevne (funkcionalne) aktivnosti ali pa uporablja tipne znake za sporazumevanje, pa je za vse »tipne« učence izrednega pomena, da razvijejo čutno (senzorično) zavest, še posebej veščine ločevanja (prepoznavanja) predmetov, in da imajo veliko izkušenj na lastni koži, ki jim pomagajo razvijati osnovne spretnosti, potrebne za življenje (Stratton in Wright, 1991).

In to je mogoče doseči z usmerjenimi vajami ter igrami, ki smo jih našteli, tako da nevsiljivo razvijemo čutno zavest, $s$ tem pa tudi branje brajice postane avtomatizirano.

Še več, vsi specialni pripomočki so nadvse zanimivi tudi za polnočutne otroke in lahko pomagajo pri njihovi motivaciji za branje. Tipna pomagala delujejo večkanalno, saj sta dostikrat poleg vida in tipa vključeni še čutili voh in sluh. Pomembno pa je tudi, da se ob srečevanju s tipankami, tipnim kamišibajem, KnjiŠko nevsiljivo spoznavajo s fenomenom slepote in poleg običajnega tiska ter povečanih črk odkrijejo brajico. Na ta način

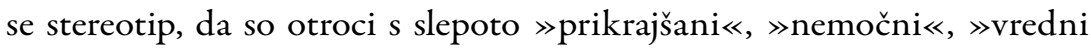
pomilovanja « ipd., ruši, saj se njihovi polnočutni vrstniki zavejo, da otroci s slepoto obvladajo veliko stvari, ki jih drugi ne znajo (na primer branje brajice). $S$ tem polnočutni razvijajo empatijo do »različnih « vrstnikov, širijo svoja obzorja in vstopajo v inkluzivno družbo.

\section{Literatura}

Batič, J., in Haramija, D. (2013) Poetika slikanice. Murska Sobota: Franc-Franc. 
Bavčar, E. (2009) Srečanje z Louisom Braillom: ob 200-letnici njegovega rojstva. V Kačič, M. in Pungertnik, S. (ur.). Louis Braille in njegov genialni izum. Ljubljana: revija RIKOSS in Zveza društev slepih in slabovidnih Slovenije.

Birch, B. (1997) Louis Braille. Slepi francoski deček, čigar izum pomaga milijonom slepih, da lahko berejo. Zbirka Véliki ljudje za boljši svet. Celje: Mohorjeva družba.

Bračič, B. (2009) Znamka z Braillovo pisavo (Bilten 74). Maribor: Pošta Slovenije.

Brambring, M. (2007) Divergent development of manual skills in children who are blind or sighted. Journal of Visual Impairment \& Blindness IOI, str. 212-225.

Brvar, R. (2000) Geografija nekoliko drugače. Didaktika in metode pouka geografije za slepe in slabovidne učence. Ljubljana: Zavod Republike Slovenije za šolstvo.

Brvar, R. (2014) Z igro do učenja. Ljubljana: Založba Math.

Cankar, G. (2013) Bralna pismenost in merjenje napredka v osnovni šoli. V Nolimal, F., in Novakovič, T. (ur.). Bralna pismenost v vrtcu in šoli. Teoretska izhodišča in empirične ugotovitve. Ljubljana: Zavod RS za šolstvo. Spletna stran: https://www.zrss.si/digitalnaknjiznica/Bralna\%2o pismenost\%20v\%2ovrtcu\%2oin\%2osoli\%20\%20Teoreticna\%2oizhodisca\%2oin\%2oempiricne\%2ougotovitve/files/assets/common/downloads/ publication.pdf (pridobljeno 20. 5. 2020).

Cervo, I. (2018) Mali prostor - pripomoček za razvoj otrokove prostorske predstavljivosti. Magistrsko delo. Koper: Univerza na Primorskem, Pedagoška fakulteta.

Claudet, P. (2009) Maintenant je sais ce que blanc veut dire. Dijon: Les Droits Que Révent, collection Corpus Tactilis.

Clay, M. M. (1966) Emergent reading behavior. Teze doktorskega dela. Nova Zelandija: University of Auckland.

Čelešnik, N. (2009) Prek ustrezne komunikacije med strokovnimi delavci in starši slepih in slabovidnih otrok do zgodnje obravnave. Vzgoja in izobraževanje 5-6, str. 62-70.

Eškirović M. B. (2015) Vizuelno funkcionisanje i slabovidnost. Beograd: Univerzitet u Beogradu, Fakultet za specialnu edukaciju i rehabilitaciju - Izdavački centar (ICF).

Gerbec, I. (1999) Braillova pisava in opismenjevanje slepih. V Gerbec, I. (ur.). Našzbornik ob 8o-letnici Zavoda. Ljubljana: Zavod za slepo in slabovidno mladino. 
Golob, M. (1999) Pot k svetlobi. Ljubljana: Zavod za slepo in slabovidno mladino.

Grbović, A. (2017) Metodski pristupi čitanju i pisanju kod slabovide dece i odraslih. Beograd: Univerzitet u Beogradu - Fakultet za specialnu edukaciju i rehabilitaciju, Izdavački centar (ICF).

Haramija D., in Knapp, T. (2019) Labko je brati, Labko branje za strokovnjake. Podgorje pri Slovenj Gradcu: Zavod Risa.

Hrastovšek, J. (2016) Program začetnega opismenjevanja v brajici. Magistrsko delo. Ljubljana: Univerza v Ljubljani, Pedagoška fakulteta.

Jablan, B. (2016) Dete sa oštećenjem vida uškoli. Beograd: Univerzitet u Beogradu, Fakultet za specialnu edukaciju i rehabilitaciju - Izdavački centar (ICF).

Kermauner, A. (200I) Tema ni en črn plašč: kako berejo slepi in slabovidni? V Mislej Božič, N. (ur.). Branje na stičišču, Zbornik simpozija. Sežana: Bralno društvo Primorske in Kosovelova knjižnica v Sežani.

Kermauner, A. (2004) Tipna slikanica za slepe. Diplomsko delo. Ljubljana: Pedagoška fakulteta.

Kermauner, A. (2013) Tipne slikanice za slepe kot univerzalni pripomoček razvijanja bralne pismenosti. V Gabrovec, R. (ur.). Tudi mi beremo - različni bralci z različnimi potrebami. Ljubljana: Zavod Republike Slovenije za šolstvo.

Kermauner, A. (2014) The Book in a Box Project. Corpus tactilis. Pragma 4, str. 109-II9.

Kermauner, A. (2018a) Informacijsko-komunikacijska tehnologija za slepe in slabovidne. V Starc, S. (ur). Oblikovanje inovativnih učnih okolij. Koper: Ludus, Založba Univerze na Primorskem.

Kermauner, A. (2or8b) Knjiga v škatli (KnjiŠka) kot pripomoček za spodbujanje branja pri nekaterih skupinah otrok s posebnimi potrebami. Inkluzivno izobraževanje: pedagoška revija za teorijo in prakso inkluzivnega izobraževanja I/2, str. 24-3I.

Kermauner, A. in Plazar, J. (2019) Prilagojeni pripomočki in metode pri vzgojno-izobraževalnem deluz otroki sposebnimi potrebami. Nova Gorica: Educa.

Koprivnikar, K. (b. d.) Predvaje za opismenjevanje v brajici. Spletna stran: http://www.sdss-sl.org/Koristni\%2onasveti/Predvaje_za_ opismenjevanje_v_brajici.pdf. (pridobljeno I0. 5. 2020).

Koprivnikar. K. (2006) Okvare vida in zgodnji razvoj otrok. V Kobal Grum, D., in Kobal, B. (ur.). Zagotavljanje enakih možnosti za vzgojo in izobraževanje slepih in slabovidnih otrokv Sloveniji. Ljubljana: DEMS. 
Kovačič, K. (2019) Spodbujanje razvoja slepih in slabovidnih dojenčkov in malčkov s pomočjo tipnih knjig in malega prostora. Magistrsko delo. Maribor: Pedagoška fakulteta Univerze Maribor.

Maljevac, M. (2019) Ustvarjanje spodbudnega igralnega okolja za otroke z okvaro vida. V Čelešnik Kozamernik, N. (ur.). Celostna obravnava, vseživljenjsko učenje in socialna vključenost oseb z okvaro vida. Ljubljana: Center za izobraževanje, rehabilitacijo, inkluzijo in svetovanje za slepe in slabovidne.

Matok, D. (2007) Metodika rada s učenicima s oštećenjem vida. V Nenadić, $\mathrm{K}$. (ur.). Učenik s oštećenjem vida u redovitoj školi. Zagreb: Hrvatski savez slijepih.

Murko, V. (2015) Pike, ki se spreminjajo v črke. Magistrsko delo. Maribor: Univerza Maribor, Pedagoška fakulteta.

Murn, T. (200I) Kajpiše na tabli? Ne vidim prebrati! Priročnik za načrtovanje in izvajanje pouka slepim ali slabovidnim učencem. Škofja Loka: Center slepih in slabovidnih Škofja Loka.

Murn, T. (2013) Vloga brajice v procesu razvoja bralne pismenosti slepih. V Gabrovec, R. (ur.). Tudi mi beremo - različni bralci z različnimi potrebami. Ljubljana: Zavod Republike Slovenije za šolstvo.

Nolimal, F. (2013) Razvoj pismenosti osnovnošolcev - od izhodišč do empiričnih ugotovitev projekta Opolnomočenje učencev z izboljšanjem bralne pismenosti in dostopa do znanja. V Nolimal, F., in Novakovič, T. (ur.). Bralna pismenost v vrtcu in šoli. Teoretska izhodišča in empirične ugotovitve. Ljubljana: Zavod RS za šolstvo. Spletna stran: https:// www.zrss.si/digitalnaknjiznica/Bralna\%2opismenost\%2ov\%2ovrtcu\%2o in\%2osoli\%20\%20Teoreticna\%2oizhodisca\%2oin\%2oempiricne\%2ougotovitve/files/assets/common/downloads/publication.pdf (pridobljeno 20. 5. 2020).

Panič, S. (2018) Slikopisi Anje Štefan v tipni obliki. Diplomsko delo. Ljubljana: Univerza Ljubljana, Pedagoška fakulteta.

Pečjak, S. (2004) V Grginič, M. in Zupančič, M. (ur.). ABC-igralnica. Priročnik. Domžale: Izolit.

Remškar, S. (2003) Možnosti književne in bralne vzgoje z revijami. Otrok in knjiga 56, str. 93-97.

Schmidt, N. (2013) Ilustracija za slepe. V Gabrovec, R. (ur.). Tudi mi beremo - različni bralciz različnimi potrebami. Ljubljana: Zavod Republike Slovenije za šolstvo.

Sitar, J. (2018) Umetnost kamišibaja. Priročnik za ustvarjanje. Maribor: Založba Aristej. 
Sokolov, C. (2009) Slikopis - mala šola branja in pisanja. V Vintar, J. (ur.). Razmerja med slikovnimi in besedilnimi sporočili: zbornik Bralnega društva Slovenije. Ljubljana: Zavod Republike Slovenije za šolstvo.

Stratton, J., in Wright, S. (1991) On the way to literacy: Early experiences for visually impaired children. American Printing House for the Blind.

Škof, M. (2017) Kamišbaj, prilagojen slepim in slabovidnim. Magistrsko delo. Maribor: Univerza Maribor, Pedagoška fakulteta.

Štefan, A. (1995) Čez griček v gozdiček. Ljubljana: Mladinska knjiga.

Toplak, A. (2012) Tipni pripomočki-pomočpri opismenjevanju slepih otrok. Magistrsko delo. Koper: Univerza na Primorskem, Pedagoška fakulteta.

Urbas, R., Kermauner, A., Reichenberg, M., in Stankovič Elesini, U. (2017) Stenska tipna zgodba: čudežno potovanje deklice Ade in kužka Benija. V Strle, M. (ur.). Aktualne vsebine spodročja specialne in rehabilitacijske pedagogike. Zbornik povzetkov: XXV. izobraževalni dnevi, Portorož, 28., 29. marec 2017. Spletna stran: http://www.drustvo-srp.si/images/ Id_2017_-_Zbornik_povzetkov_K.pdf (pridobljeno I0. 5. 2020).

Vachulova, J. (2009) Books in Boxes and glued objects. V Tiphlo \& Tactus Guide to children's books with tactile illustrations. Dijon: Les Doigts qui Révent.

Zidarič, M. (2014) Značilnosti igre slepih in slabovidnih otrok. Specialna in rehabilitacijska pedagogika: revija specialnih in rehabilitacijskih pedagogov Slovenije. Ljubljana: Društvo specialnih in rehabilitacijskih pedagogov in Center Kontura.

Žunič, D. (2019) Zgodnja obravnava otrok s posebnimi potrebami v Sloveniji. V Strle, M. (ur.) Skrbnih sedemdeset - 7o let organiziranega povezovanja specialnih in rehabilitacijskih pedagogov Slovenije Zbornik. Ljubljana: Društvo specialnih in rehabilitacijskih pedagogov Slovenije. 